\title{
IMPROVING VOCABULARY AND TAHAJJUD HABIT USING CHAIN SMS IN TAHAJJUD TIME FOR THE FIFTH GRADE STUDENTS OF MI AL MUBAROK WANGKAL SIDOARJO
}

\author{
Muflikh Wakhidi ${ }^{1)}$ \\ Email: abielonny@gmail.com \\ Rakhmawati ${ }^{2}$ \\ Email: thestarone_777@yahoo.com \\ Ana Nurul Laila ${ }^{2}$ \\ Email:ananurullaila@uinsby.ac.id \\ ${ }^{1)}$ Madrasah Ibtidaiyah Al Mubarok, Sidoarjo \\ ${ }^{2}$ Universitas Islam Negeri Sunan Ampel Surabaya
}

\begin{abstract}
Vocabulary is an important aspect in the process of learning English because it is needed by the students when they are learning English language skills. Therefore, teaching English in primary schools are held to provide students a larger amount of vocabulary than what they probably have before. This research is designed to improve the students' vocabulary as well as their Tahajjud (night prayer) habit using Chain SMS sent during Tahajjud time. The method was selected because it was believed to be able overcome the problem of limited time at school and allow students to memorize vocabulary gradually since they will learn after they have enough rest and after they did they tahajjud prayer. This is a a Classroom Action Research (CAR) designed in two cycles. The subjects of this research were 29 students of the fifth grade of $\mathrm{MI} \mathrm{Al}$ Mubarok Wangkal in the 2014/2015 academic year. The data of this research study were obtained through vocabulary test documentation. The findings of this research indicated that the Chain SMS in Tahajjud time was successful in improving both the students' ability in vocabulary and the students' Tahajjud habit. The improvement can be seen from the increase of students' scores and the students' individual score percentage from preliminary study to Cycle 2 both for vocabulary achievement and Tahajjud prayer habit.
\end{abstract}

Key Words: Vocabulary, Chain SMS, Tahajjud 


\section{INTRODUCTION}

English language has been taught in primary schools to provide students with the basic knowledge and vocabulary of an international language. According to the National Education Minister Number 2223/2006 on the Standard Content and Standard Competency, the learning of English in primary schools (SD/MI) is directed to develop the skills of listening, speaking, reading, writing, and the graduate are able to communicate and discourse in English at the level of literacy performance. In the per formative level, people are able to listen, speak, read, and write with the symbols used. By mastering enough vocabulary in the early age, the students should be able to master the English language easier when they go to the higher level of education.

However, based on the researcher experience during teaching English at MI Al Mubarok Wangkal, the students had low of mastering vocabulary. It can be seen from the Minimum Completeness Criteria (KKM), students' grades, and the results of pre-condition conducted on students in fifth grade of MI Al Mubarok Wangkal that shows they have low average of vocabulary ability. Based on the researcher observation, the low vocabulary mastery can occur for several reasons, among others, the strategies used by teachers in teaching this language (instructional design and teaching methods) could be monotonous and less challenging for students to be able to master the English. In teaching English, especially vocabulary, teachers in this school used student worksheet without involving any media. While the teaching and learning activities, students are required to memorize more than twenty words in just 10 minutes, and sometimes there is no time to memorize. This shows that students do not memorize vocabulary gradually, little by little, but the entire existing vocabulary. Students were not given enough time to memorize the vocabulary. As the result, the students only can memorize a little number of the vocabulary and it is easily forgotten by students. Of course, this needs to be addressed to maximize the teaching and learning activities.

One way to overcome these problems is to use the chain SMS. This method can overcome the problem of limited time at school and allow students to memorize vocabulary gradually. Shuler identified some opportunities in mobile learning, included SMS. They are 
encourage 'anywhere, anytime' learning, reach underserved children because of their relatively low cost and accessibility in low-income communities, improve twenty-first century social interactions, fit with learning environments, and enable a personalized learning experience (Pachler et.al, 2010: 9). The uses of SMS messaging for tutoring is enabling students to focus on the academic content, to come better prepared for tutorials and to be more ready to participateactively in discussions, to ask more questions and more freely at that, to be more easily absorbed (Abas, et al, 2011: 158).

Lu, (as cited in Motallebzadeh and Ganjali, 2011: 112), found that the group that was taught vocabulary using mobile media better than those who use the media in a vocabulary book in one week duration. In Motallebzadeh, Thornton and Houser also made a comparative study of the effectiveness of learning vocabulary by email and via phone, revealed that the groups using mobile media has reached a vocabulary more than the group using the email medium. While the group using the email media reach a better vocabulary than in the group that used the book as a medium of learning vocabulary. They concluded that mobile media can increase their interest and encourage more effective student learning opportunities in acquiring new vocabulary.

Madrasah Ibtidaiyyah Al Mubarok already incorporates English into the curriculum since 1994. In the span of twenty-one years of learning English, the school seeks to produce alumnus who are able to master English well. In addition, as a distinctively Islamic school, this school also aims to produce students who are able to apply the Islam value in daily life. Therefore, in the implementation of the Education Unit Level Curriculum (KTSP), religious values are always integrated into the learning process, including the subjects in English.

Based on the above reasons, the study focuses on answering the questions on the students' vocabulary improvement as well as their Tahajjud prayer habit when they are encourage to study vocabulary using Chain SMS in Tahajjud time. This study will only focus on the fifth grade students at MI Al Mubarok Wangkal Academic Year of 2014/2015. 


\section{THE PRINCIPLES FOR TEACHING VOCABULARY FOR YOUNG LEARNERS}

Vocabulary is an important element in a language besides pronunciation and grammar. Vocabulary supports the speakers in communication to express their idea in the target language. The researcher would like to present several definitions about vocabulary before giving more explanation.

There are some definitions of vocabulary proposed by linguist. Hatch and Brown stated that vocabulary is a list or set of words for a particular language or a list or set of words that individual speakers of a language might use. It means vocabulary is a series of words used by individual speakers of certain language. Since vocabulary is a list, the only system involved is alphabetical order in dictionaries. Here, vocabulary is written in alphabetical order in dictionaries based on the system or rule of the foreign language (Hatch, 1995: 1). Different from the definition above, Ur said that vocabulary can be defined as the words we teach in the foreign language (2009: 60). It means vocabulary is written or spoken unit of language as symbol of idea in foreign language introduced to learners. If a teacher teaches new words in foreign language, it means the teacher teaches vocabulary. An item of vocabulary may be more than a single word: for example post office, mother-in law, which are made up of two or three words but expressing a single idea.

Based on the definitions above, vocabulary can be defined as a series of words in the foreign language used to express meaning. Here, words are symbols in the form of groups of letter represent, either a physical object or an idea. It can be formed from a single word or more than one word.

On teaching vocabulary to young learners, Cameron (2005: 81) states several principles, they are:

a. The types of words that children find possible to learn with shift.

b. Vocabulary development is not just learning more words but it is also importance about expanding and deepening word knowledge.

c. Words and words knowledge can be seen as being linked in network of meaning. 
d. Basic level words are likely to be more appropriate for children, or when learning vocabulary for new concepts.

e. Children change in how they can learn words.

Looking at the importance of English as foreign language to young learners, the teaching principles will influence the foreign language learners' understanding toward the material that is taught. That is the reason why the teaching process must be based on an appropriate strategy referred to the teaching principles. The learners, through a well teaching process and structurally transferred, will gain a good English foundation.

\section{The Characteristics of Elementary School Student}

In general, the Elementary school students are the children at the age between six up to twelve years old which are enthusiastic to know and learn everything (Cameron, 2005: 1). The following are some general characteristics as the children of that group according to Scott (1990: 3):

a. They are competent users of mother tongue.

b. They can tell the difference between fact and fiction.

c. They love to play and learn best when they enjoy themselves seriously and like to think that what they are doing in real work.

d. They are enthusiastic and positive about learning.

e. They rely on the spoken as well as the physical word to convey and understand meaning.

f. They are able to work with others and learn from others.

g. Their own understanding comes through eyes, hands and ears. The physical word is dominant at all times.

h. They have very short attention and concentration span.

Harmer (2007: 82) also states some general characteristic of children, as follows:

a. They respond to meaning even if they do not understand the words.

b. They often learn indirectly than directly.

c. Their understanding comes not just from the explanation, but also from what they see and hear and crucially have a chance to touch and interact with. 
d. They generally display an enthusiasm for learning and curiosity about the world around them.

e. They have a need for individual attention and approval from their teacher.

f. They are keen on talking about themselves and responding well to learning that use themselves and their own lives as main topic in the classroom.

g. They have limited attention span, unless activities are extremely engaging can make them easily getting bored, losing interaction after 10 minutes or so.

Based on the points stated by Wendy and Hammer above, the researcher assumes that Elementary school students are very enthusiastic in finding out, understanding and learning everything. It seems that they like learning something that involves a new thing and the elements of fun where they can laugh, talk, and feel happy during the class. The most important thing is that they can enjoy and absorb the sense of the lesson.

\section{TAHAJJUD}

هجد الرجل Ibn Manzur in the Lisanul 'Arab explained, said which means that if a person sleep at night. The word منهجد "mutahajjid" is a person who wakes from sleep to perform prayers (as cited in Muhammad, 1119: 4616). In summary, the definition of Tahajjud is a person who does sunnah prayer after woke up from his sleep at night even though they only briefly to have sleep.

Tahajud is done at the beginning, middle or end of the night. Ibn Hajar explained that the prayer night and sleep time of the Prophet is different every night. He did not set a specific time for prayer. But he did it according to the situation that was easy for him (al Atsqalany, 1963: 3).

Meanwhile, the most important time for evening prayer is at the end of the night. As a hadith was narrated by Abu Hurairah that the Prophet said:

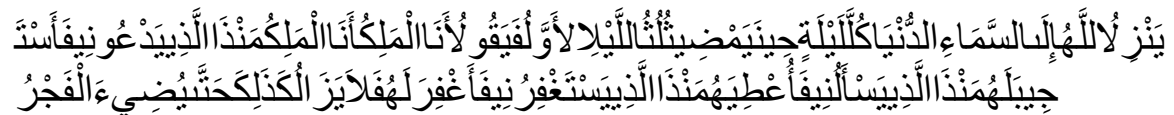


"Allah descends every night to the lowest heaven when one-third of the first part of the night is over and says: I am the Lord; I am the Lord: who is there to supplicate Me so that I answer him? Who is there to beg of Me so that I grant him? Who is there to beg forgiveness from Me so that I forgive him? He continues like this till the day breaks."

The second hadith which strengthens the above statement is a hadith of 'Abdullah bin' Amr. He reported that the Prophet said:

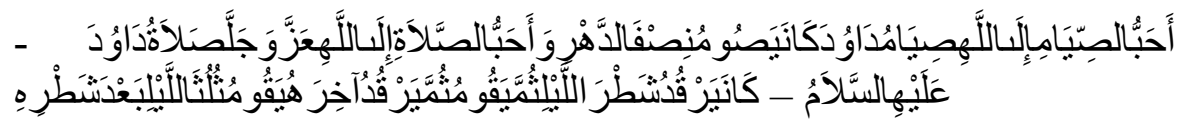

"The best fasting in the eye of Allah is that of David, for he fasted for half of the age (he fasted on alternate days), and the best prayer in the eye of Allah, the Exalted and Majestic, is that of David (peace be upon him), for he slept for half of the night and then stood for prayer and then again slept. He prayed for one-third of the night after midnight."

However, for people who are worried about not being able to get up late in the evening, then let the evening prayer at the beginning of time. As for those who believe he can get up the night so that the main work on the end of the night. Rasulullah said:

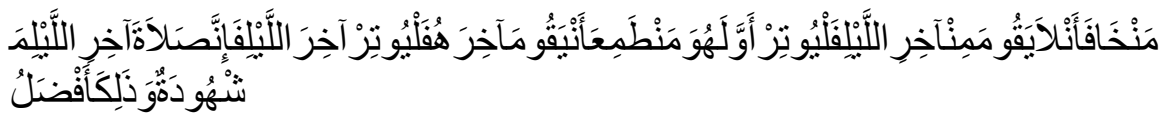

"If anyone is afraid that he may not get up in the latter part of the night, he should observe Witr in the first part of it; and if anyone is eager to get up in the last part of it, he should observe Witr at the end of the night, for prayer at the end of the night is witnessed (by the angels) and that is preferable." ${ }^{\text {3 }}$

\footnotetext{
${ }^{1}$ Abu Husain Muslim Hajjaj-al-Qusyairi An-Naisaburi, Shahih Muslim, (Beirut: Dar Ihya at Turats Alrabi, 1954),

${ }^{2}$ Abu Husain Muslim Hajjaj-al-Qusyairi An-Naisaburi, Shahih Muslim, .. 812

${ }^{3}$ Abu Husain Muslim Hajjaj-al-Qusyairi An-Naisaburi, Shahih Muslim, .. 519
} 


\section{RESEARCH METHODOLOGY}

This research used Classroom Action Research (CAR) because the researcher assessed the effectiveness of his own teaching activities and planed the improvement based on the result of assessment.

For this study test and observation check list are employed. The test sheet, used to know the improvements of the students' vocabulary, consisted of multiple choices questions. The researcher conducted the test which consists of 20 items which should be done in 30 minutes. The test covered two topics, Hobbies and Transportation. Simple statistics is applied to know the result of the test. To analyze the Tahajjud habit improvement in each cycle, the students were given Students' Daily Activity as a journal for them to write what they did during Tahajjud time.

\section{Planning}

Firstly the researcher decided the topic of lesson. Secondly, the researcher made a lesson plan and designed the steps in doing the action based on the treatment carried out. The researcher made the scenario of the teaching learning process for the treatment.

One week before the learning process was implemented, a text message containing 4-5 new vocabulary was sent to the students. This text message was to be forwarded to one of the last members. SMS delivery was done every day in five days during Tahajjud time with different vocabulary every day. Then the researcher prepared a test to know whether the students' vocabulary mastery improved or not by using multiple choice questions.

The researcher then set the success criteria. This research is able to be called successful if it can exceed the criterion which has been determined, and fail if it was cannot exceed the criterion which has been detained. In this research, the research succeeded when there were two criterions. First, there were 75\% numbers of students could achieve some vocabulary improvement scores from the pre-condition until the second post-condition in cycle two or they could pass the 
target score of the Minimum Completeness Criteria (KKM). The KKM that must be attained was 70 (seventy) which was adapted from the curriculum document. ${ }^{4}$ Second, it is $75 \%$ numbers of students could achieve some Tahajjud improvement scores from the preliminary study until the last cycle two or they could pass the target score of the Minimum Completeness Criteria (KKM). The KKM must be attained score B $\left(61\right.$ - 80) which was adapted from the Curriculum Document. ${ }^{5}$ If the criteria of the action success achieved, it meant that the next action of the Classroom Action Research (CAR) would be stopped, but if this condition has not been reached yet, the alternative action would be done in the next cycle.

\section{Acting}

In this step, the researcher did the planning that had made on the planning step. The researcher conducted classroom activity under Chain SMS as the treatment. The material that was used in this treatment was the list of vocabulary that was send by SMS.

\section{Observing}

The observation was done during teaching and learning process. The researcher was the observer in the classroom. The researcher observed and wrote down the process happen during the action. In the end of the meeting, the researcher given vocabulary test (post-condition) to know whether the students' vocabulary had improve through the use Chain SMS or not. The result of the post-condition was compared with the pre-condition result. The result of post-condition also compared to the criteria of success. Thus, the data of this research was used to be analyzed for teacher's reflection.

\section{Reflecting:}

In this step, the researcher reflected the cycle that had been doing. The researcher evaluated the teaching learning process. Then the researcher reflected by check result of the students' test. If the students' score was less than the success criteria, the cycle revised and done again using next cycle using revised of the reflecting of the cycle before.

\footnotetext{
${ }^{4}$ Madrasah Ibtidaiyyah Al Mubarok Wangkal, Dokumen Kurikulum Tingkat Satuan Pendidikan (Sidoarjo: ... ,2014), 146

${ }^{5}$ Ibid, 149
} 


\section{RESULTS}

The result of post-condition in cycle 2 showed in this figure:

Figure 1 Students' Vocabulary Score Post-condition in Cycle 2

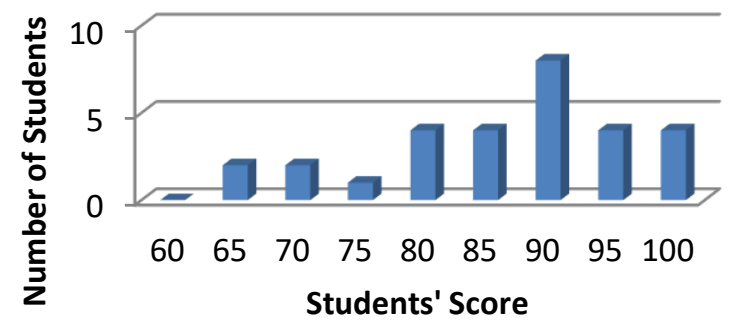

Based on the result of post-condition in cycle 2, it showed that there were 2 students still low in vocabulary. It has been significantly reduced as compared with the results of the pre-cycle. We also could see that the lowest score was 65 or greater 25 point than the precondition result. And the highest score was 100 or greater 20 point than pre-condition result. From 29 students, there was not any student got 60 and 2 students got 65, 2 student got 70, 1 student got 75, and 4 students got 80 and 4 students got 85,8 students got 90,4 students got 95 , and 4 students got 100 . Based on the figure, we known that the most score obtained by the students was 90 .

Whereas to determine the number of students who have achieved a Minimum Completeness Criteria (KKM), we can see the figure below:

Figure 2 Students' Vocabulary Achievement in Post-condition in Cycle 2 


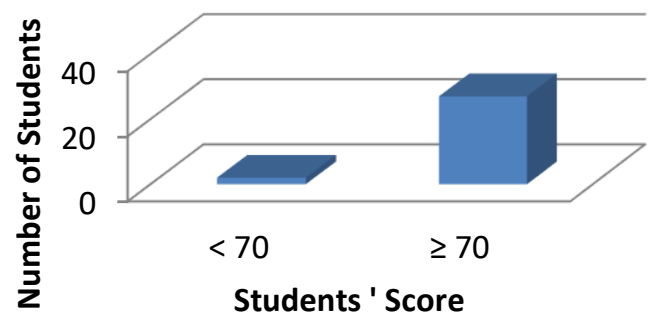

From the figure 4.7, we knew that students who got equal to or greater than score 70 were 27 students and 2 students got less than score 70. Based on the previous description that the students were said to be completed if they achieved the Minimum Completeness Criteria (KKM) or got equal to or more than score 70, thus students who achieved the Minimum Completeness Criteria (KKM) in the cycle 2 were 27 students.

Based on the data, we knew that the mean score of students' vocabulary mastery in cycle 2 was more than Minimum Completeness Criteria (KKM) and the number of students who were able to reach Minimum Completeness Criteria (KKM) more than the criteria of success in this research. It implied that the criterion has fulfilled in this cycle.

Furthermore, if we compared the research results in cycle 2 with precycle the result could be illustrated by the figure below:

Figure 3 Students' Vocabulary Achievement in Pre-condition and Postcondition in Cycle 2

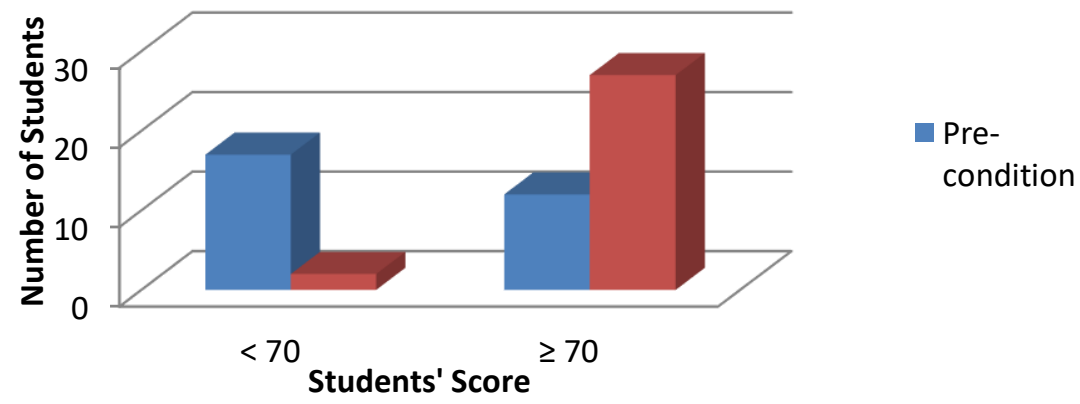

Based on the figure, there were 17 students got score less than 70 in pre-cycle and it reduced to 2 students in cycle 2 . On the other hand, there were 12 students got score more than 70 in pre-cycle and 
it increased to 27 students in cycle 2. It was an increase on the number of students who achieved equal to or more than score 70 as many as 15 students from pre-cycle to cycle 2.

The improvement percentage of students who achieved Minimum Completeness Criteria (KKM) in cycle 2 was derived from the formula:

$P=\frac{y 2-y}{y} \times 100 \%$

$P=\frac{86.38-61.90}{61.90} \times 100 \%$

$P=39.56 \%$

Thus, there was improvement vocabulary mastery from pre-cycle to cycle 2 .

\section{Students' Tahajjud Habit Improvement Using Chain SMS}

The result of cycle 2 showed in this figure:

Figure 4 Students' Tahajjud Habit Frequency in Cycle 2

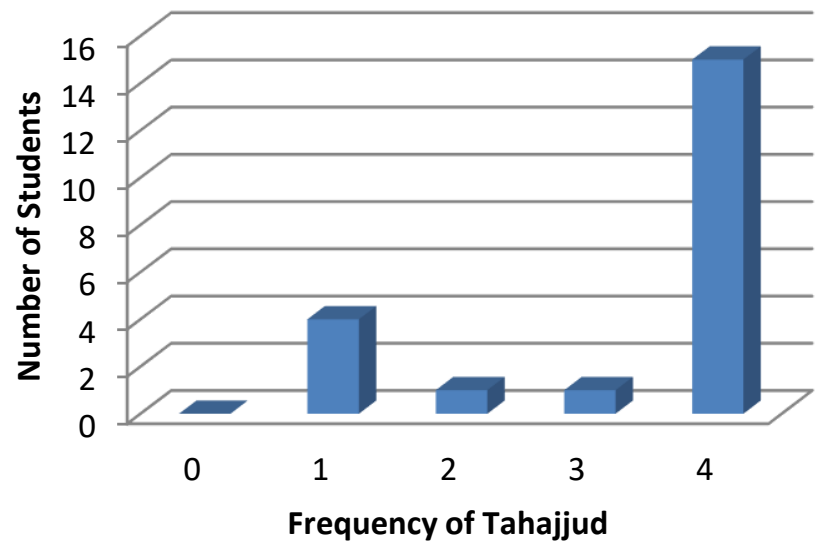

Based on the result in cycle 2, it showed that many students still low in Tahajjud habit. From 29 students, there was not a student never did Tahajjud, 4 students did once, 1 student did twice, 1 student did three times, 15 students did four times, and 8 students did five times. Based on the figure, we knew that the most of students never done Tahajjud. 
Whereas to determine the number of students who have achieved a Minimum Completeness Criteria (KKM), we could see the figure 4.15 below:

Figure 5 Students' Tahajjud Habit Achievement in Cycle 2

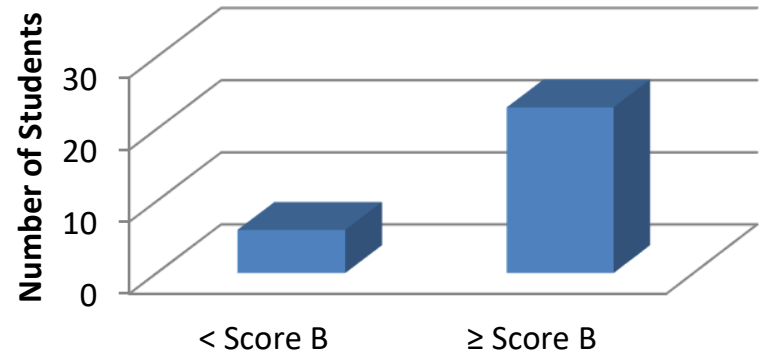

Students' Score

From the figure 4.15 , we knew that students who got equal to or greater than score B were 23 of 29 students and 6 students got less than score B. Based on the previous description that the students were said to be completed if they achieved the Minimum Completeness Criteria (KKM) or got equal to or more than score B, the students who achieved the Minimum Completeness Criteria (KKM) in the cycle 2 were 23 students.

Thus, the percentage of students who passed the KKM score was calculated using the following formula is $79.31 \%$.

Based on the data, we knew that the mean score of students' Tahajjud habitwasmore than Minimum Completeness Criteria (KKM) or more than score B. Based on the cycle completeness criteria that it was called completed if the number of the each student that was completed reach of 22 students. In this research the number of students who were able to reach Minimum Completeness Criteria (KKM) mpre than 22 students. Thus, the second cycle in this research completed.

Furthermore, if we compared the research results in cycle 2 with pre-cycle the result could be illustrated by the figure below: 
Figure 6 Students' Tahajjud Habit Achievement in Pre-cycle and cycle 2

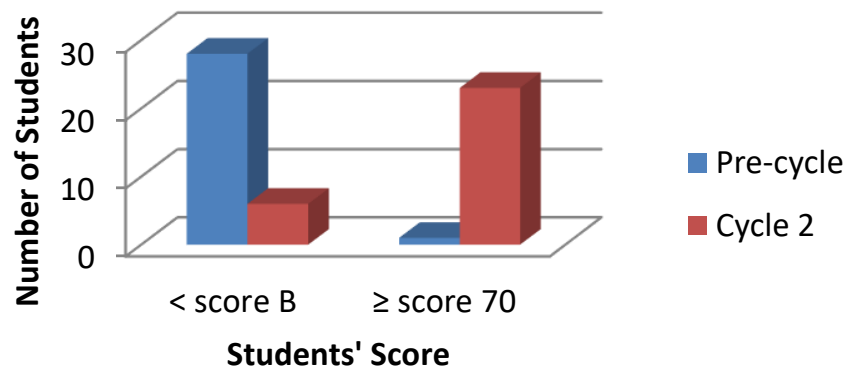

Based on the figure, there were 28 of 29 students got score less than score B in pre-cycle to 6 students in cycle 2 and it was reduced about 22 students. On the other hand, there was 1 of 29 students got score more than score B in pre-cycle and it increased to 23 students in cycle 2. It was an increase on the number of students who achieved equal to or more than score B as many as 22 students from pre-cycle to cycle 2 . And also, there was increase of mean of class score.

The improvement percentage of the students who got score B in cycle 2 derived from the formula:

$$
\begin{aligned}
& P=\frac{y 2-y}{y} \times 100 \% \\
& P=\frac{75.17-9.66}{9.66} \times 100 \% \\
& P=966.00 \%
\end{aligned}
$$

Thus, there was an significance increase frequency of implementation Tahajjud in cycle 2 or it was better than the pre-cycle results. 


\section{DISCUSSION}

Chain SMS in Tahajjud time is an effective method in improving the students' vocabulary and Tahajjud habit. It is related on the data analysis of the students' vocabulary and Tahajjud habit achievements before implementing Chain SMS in Tahajjud time and after implementing it.

In improving students' vocabulary, the researcher could see the progress or improvement of it. It was figured in this graphic and table below.

\section{Figure 7 Differences of Test Result}

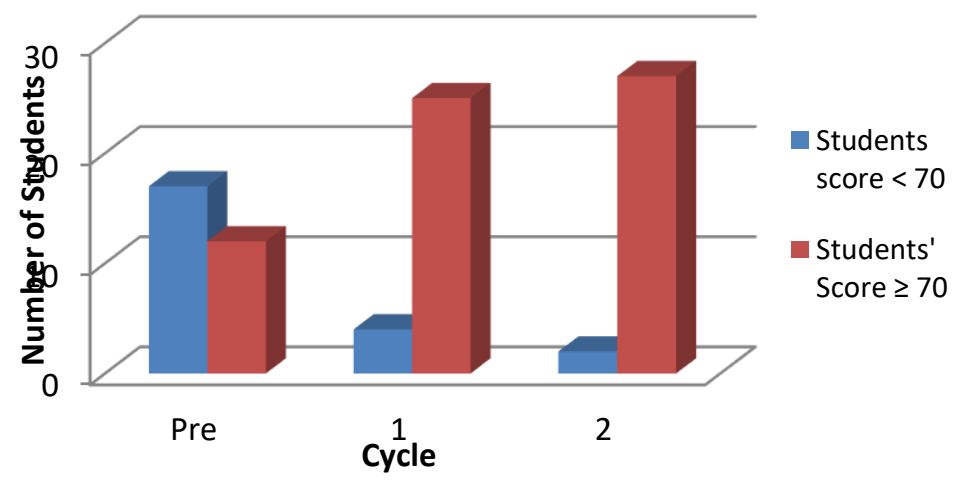

Based on the figure, there were 17 students got score less than 70 in pre-cycle and it reduced to 4 students in cycle 1 and 2 students in cycle 2. On the other hand, there were 12 students got score more than 70 in pre-cycle and it increased to 25 students in cycle 1 and 27 students in cycle 2. It was an increase on the number of students who achieved equal to or more than score 70 as many as 13 students from pre-cycle to cycle 1 and 25 students in cycle 2 . It meant that there was students' vocabulary improvement in each cycle using Chain SMS in Tahajjud time.

Table 1. Test Result

\begin{tabular}{|c|c|c|c|c|c|c|}
\hline \multirow[b]{2}{*}{ No } & \multirow[b]{2}{*}{ Test Result } & \multicolumn{2}{|c|}{ Score $<70$} & \multicolumn{2}{|c|}{ Score $\geq 70$} & \multirow[b]{2}{*}{$\begin{array}{c}\text { Improvement } \\
\text { Percentage } \\
(\%)\end{array}$} \\
\hline & & $\begin{array}{c}\text { Number } \\
\text { of } \\
\text { Students }\end{array}$ & $\%$ & $\begin{array}{c}\text { Number } \\
\text { of } \\
\text { Students }\end{array}$ & $\%$ & \\
\hline 1 & Pre-condition & 17 & 58.6 & 12 & 41.4 & - \\
\hline 2 & Post-condition & 4 & 13.8 & 25 & 86.2 & $40.10 \%$ \\
\hline
\end{tabular}




\begin{tabular}{|c|c|c|c|c|c|c|}
\hline & Cycle 1 & & & & & \\
\hline 3 & $\begin{array}{c}\text { Post-condition } \\
\text { Cycle 2 }\end{array}$ & 2 & 6.4 & 27 & 93.1 & $39.56 \%$ \\
\hline
\end{tabular}

Based on Table 1, it showed that there are 12 students who get score greater than or equal to 70 . It meant that the students who obtain test score greater than or equal to 70 are less than 22 students of the whole class and 17 students get score less than 70 .

The students' score on the cycle 1 showed that there were 25 students who get score greater than or equal to 70 and 4 students get score less than 70. This meant that the criteria of success are achieved because students who get test score greater than or equal to 65 are more than 22 students of the whole class. Thus, there was an improvement students' vocabulary mastery.

The students' score on the cycle 2 showed that there were 27 students who get score greater than or equal to 70 and 2 students get score less than 70 .

It meant that the success criteria of vocabulary improvement was achieved because students who get test score greater than or equal to 70 are more than 22 students of the whole class. Thus, there was an improvement students' vocabulary mastery.

In improving students' Tahajjud habit, the researcher could see the progress or improvement of it. It was figured in the graphic and table below.

Figure 8 Students' Tahajjud Habit Achievement

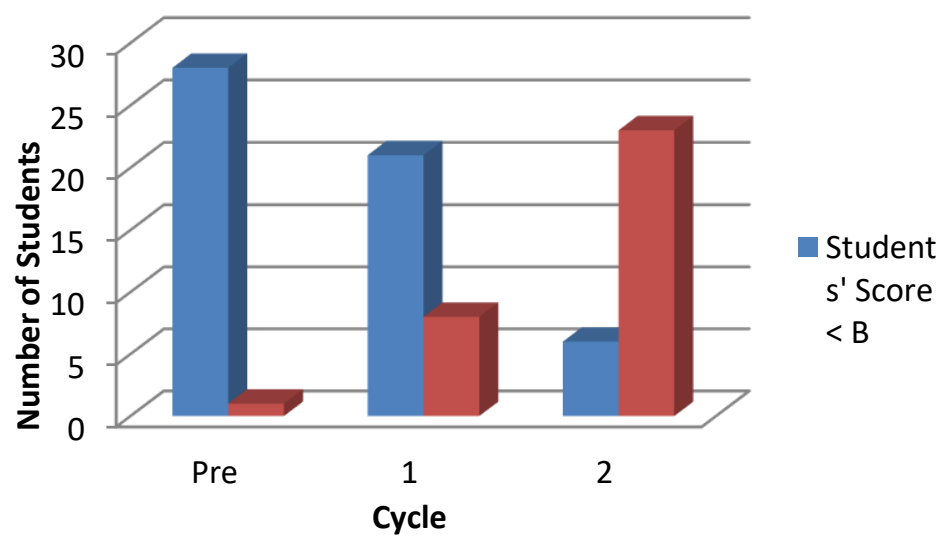


Based on the figure, there were 28 of 29 students got score less than score B in pre-cycle to 21 students in cycle 1 and 6 students in cycle 2 and it was reduced about 22 students. On the other hand, there was 1 of 29 students got score more than score B in pre-cycle and it was increased to 8 students in cycle 1 and 23 students in cycle 2. It was an increase on the number of students who achieved equal to or more than score B as many as 22 students from pre-cycle to cycle 2. It meant that there was students' Tahajjud habit improvement in each cycle using Chain SMS in Tahajjud time.

Table 2 Students' Tahajjud Habit Achievement

\begin{tabular}{|c|c|c|c|c|c|c|}
\hline \multirow[b]{2}{*}{ No } & \multirow[b]{2}{*}{ Cycle } & \multicolumn{2}{|c|}{$<$ Score B } & \multicolumn{2}{|c|}{$\geq$ Score B } & \multirow[b]{2}{*}{$\begin{array}{c}\text { Improvement } \\
\text { Percentage } \\
(\%)\end{array}$} \\
\hline & & $\begin{array}{l}\text { Number } \\
\text { of } \\
\text { Students }\end{array}$ & $\%$ & $\begin{array}{c}\text { Number } \\
\text { of } \\
\text { Students }\end{array}$ & $\%$ & \\
\hline 1 & Pre-cycle & 28 & 96.5 & 1 & 3.4 & - \\
\hline 2 & Cycle 1 & 21 & 72.4 & 8 & 27.5 & 356.94 \\
\hline 3 & Cycle 2 & 6 & 20.7 & 23 & 79.3 & 966.00 \\
\hline
\end{tabular}

Based on the table 4.2 and figure 4.18 , it showed that there was 1 student who get score greater than or equal to score B. It meant that the students who obtain score greater than or equal to score B are less than 22 students of the whole class and 28 students get score less than score B.

The students' score on the cycle 1 showed that there are 8 students who get score greater than or equal to score B and 21 students get score less than score B. This meant that the criteria of success was not achieved because students who get test score greater than or equal to score B are still less than $75 \%$ students of the whole class. Because of the cycle 1 the completeness criteria are not achieved, the cycle is continued to the next cycle. Although the scores achieved did not achieve the completeness criteria, but in this cycle, the number of students and the Tahajjud frequency already showed a significant improvement.

The students' score on the cycle 2 showed that there were 23 students who get score greater than or equal to score B and 6 students get score less than score $\mathrm{B}$. This meant that the criteria of success are 
achieved because students who get score greater than or equal to 65 are more than 22 students of the whole class. And if we compared to the results in pre-cycle, this cycle has reached an amazing significant improvement.

This research set out to explain the use of the Chain SMS to improve students' vocabulary and habits Tahajjud. There are two main questions that attempted to be answered by this research, with regard to the result achieved in improving vocabulary and Tahajjud habit. The first question is to know the vocabulary improvement that is achieved by using the Chain SMS. It showed there was a significant improvement vocabulary before and after implementation of the Chain SMS in Tahajjud time in cycle 1and cycle 2. The achievement of completeness criteria was achieved in the cycle 1 . It meant that there was a students' vocabulary improvement using Chain SMS in Tahajjud time.

The results are in accordance with the $\mathrm{Lu}$ research. $\mathrm{Lu}$, in Motallebzadeh, found that the group that was taught vocabulary using mobile media better than those who use the media in a vocabulary book in one week duration. In Motallebzadeh, Thornton and Houser also revealed that the groups using mobile media has reached a vocabulary more than the group using the email medium (2011: 112). And it is also in accordance with the results of the Abas research. Abas stated that SMS could improve the vocabulary ability which better than using audio and video medium (Abas, et al, 2011: 169).

The second research question focused on improving students' Tahajud habits. The results showed that the use of Chain SMS in Tahajjud time can improve students' Tahajjud habit. Based on the number of whole students who done Tahajjud, using this method provided a dramatic improvement in improve students' Tahajud habit. And based on the Tahajjud frequency, this method showed a significance improvement. The results also showed that to complete the completeness criteria Tahajjud needed a greater effort because it involved the parents' role for guiding students to carry out Tahajjud.

This research was not without limitations. The limitation was that the study did not specifically identify how often students learn vocabulary by phone. Considering to the importance of repetition for 
improving vocabulary, the research could not explain whether they use mobile phones for at a different time and place.

\section{REFERENCES}

Abbas, Z. W et.al. (2011). Unleashing the Potential ofMobile Learning through SMS Text for Open and Distance Learners. In Andrew Kitchenham (Eds.), Modelsfor Interdisciplinary Mobile Learning: Delivering Information to Students. Hershey: Information Science Reference.

Abul Fadal Jamaluddin Muhammad bin Makram bin Manzur al-Afriqi al-Misri. (1119). Lisan al-Arab Cairo: Darul Ma'arif

al-Atsqalany, I. B. (1963) Fathul Bari. Beirut: Dar al-Ma'rifah.

Cameron, L. (2005) Teaching languages to Young learners. Cambridge: Cambridge University Press.

Harmer, J. (2007) The Practice of English Language Teaching. England: Pearson Education Limited.

Hatch, E. and Brown, C. (1995). Vocabulary, Semantic and Language Education. New York: Cambridge University Press.

Motallebzadeh, K and Ganjali, R. (2011) "SMS: Tool for L2 Vocabulary Retention and Reading Comprehension Ability". Journal of Language Teaching and Research, 2(5), pp. 1111-1115. DOI: 10.4304/jltr.2.5.1111-1115

Pachler, N., et.al. (2010). Mobile Learning: Structures, Agency, Practices. New York: Springer Science.

Scott, W. A and Ytreberg, L. H. (1990) Teaching English to Children. New York: Longman 